\title{
First isolation of dengue 1 virus from Aedes aegypti in Federal District, Brazil
}

\author{
Primeiro isolamento do vírus dengue 1 a partir de Aedes aegypti \\ no Distrito Federal, Brasil \\ Nicolas Dégallier ${ }^{1}$, José Marcus S. Teixeira² ${ }^{2}$ Paulo de Tarso R. Vilarinhos ${ }^{3}$, \\ Santuzza C.F. Pinto ${ }^{2}$ and Regilene D. Pereira ${ }^{2}$
}

\begin{abstract}
Dengue is present in the Federal District since 1991 and virological studies of the vector began in 1998. Two strains of DEN1 were isolated from 9 pools of female Aedes aegypti (78 mosq.), collected in April in Gama county, where the Breteau index was 5.4, and 32 autochtonous human cases were notified.
\end{abstract}

Key-words: Isolation. DEN1. Aedes aegypti. Federal District.

Resumo A dengue está presente no DF desde 1991 e estudos virológicos sobre o vetor iniciaramse em 1998. Duas amostras de DEN1 foram isoladas de 9 lotes de fêmeas de Aedes aegypti (78 ind.), coletadas em abril no Gama, onde o índice de Breteau era 5,4 e 32 casos autoctones foram notificados.

Palavras-chaves: Isolamento. DEN1. Aedes aegypti. Distrito Federal.

Imported dengue cases have been notified and laboratory-confirmed in Federal District (FD) since $1991^{4}$, with 9 isolations of DEN 2 virus ${ }^{8}$. From 1993 onwards, the number of cases increased, with detection of five autochtonous cases in 1997. During the first half of 1998, 296 and 13 cases were confirmed serologically (MAC ELISA) and by viral isolation, respectively. Of these, 75 were autochtonous, and the local transmission of DEN 1 virus was confirmed by 3 isolations. The Gama county alone, located at the border of Goias State, provided 32 autochtonous cases (2 DEN 1 isolates) and was thus considered a high risk area.
Entomological surveys were conducted in houses where cases were suspected to be autochtonous. Mosquitoes were collected as they landed on people during afternoon. They were anaesthetized by cold, pooled (20 spec. max.) by species and sex, and conserved at $-70^{\circ} \mathrm{C}$ until inoculation. The pools were inoculated in $\mathrm{C6} / 36$ cell cultures (Ae. albopictus). In the absence of cytopathic effect until the $7^{\text {th }}$ day, a blind passage was done and then tested on 14th day by indirect immunofluorescence test with monoclonal antibodies to dengue 1-49.

Instituto de Saúde do Distrito Federal (ISDF), Brasília, DF, Brasil.

1. IRD, C.P. 7091 Lago Sul, 71619-970 Brasília DF, Brasil; Telefax: 0 xx 61 226-4813; E-mail: degallie@solar.com.br

2. ISDF/Virologia, SGAN Q601 lotes O e P, 70830 Brasília DF, Brasil.

3. GCZ/ISDF, SAIN, Estr. do Contorno do Bosque lote 04, 70620-000, Brasilia DF, Brasil; E-mail: vilapaul@persocom.com.br

Financial and logistic support: National Health Foundation, Health Institute of Federal District - Health Secretary of FD, Brasil \& Research Institute for Development (IRD, formerly ORSTOM), France.

Address to: Dr. Nicolas dégallier. C.P. 7091 Lago Sul, 71619-970 Brasília DF, Brasil; Telefax: 0 xx 61 $226-4813$.

E-mail: degallie@solar.com.br

Recebido para publicação em 31/3/99. 
A total of 117 mosquitoes (78 females and 39 males) was collected in 5 houses in Gama county, and pooled ( 9 and 7 pools of female and male, respectively). DEN 1 virus ${ }^{5}$ was isolated from 2 pools of 4 Aedes aegypti females, collected on 27 April 1998, in Engenho das Lages, located $30 \mathrm{~km}$ from Brasilia on road BR060. Two other pools, made of 21 males, were negative. The owner of the house from which the positive mosquitoes originated began illness on $1^{\text {st }}$ April, thus approximately 4 weeks before the capture of the mosquitoes was $0.45 \mathrm{mosq} /$ man $x$ hour (during mid afternoon) and, during the month of April, the larval house and Breteau indexes in Gama county were $3.8 \%$ and 5.4 , respectively.

To our knowledge, isolation of dengue virus from Ae. aegypti in Brazil has been reported only three times, despite the rise in epidemics during the last 15 years $^{3}$. Some attempts failed to isolate any strain from mosquitoes, despite the great numbers of human cases ${ }^{110}$. The present study reports isolation of dengue 1 virus from adult female mosquitoes, in a context of low transmission rate (no. human cases / inhabitant) and low mosquito density, in contrast with former studies in other regions of Brazil ${ }^{2}$. In the study done in Niterói during an epidemic, isolations from mosquitoes were associated with high house and Breteau indexes $(35.2 \% \text { and } 102 \text {, respectively })^{2}$. On the other hand, transmission with a low level of mosquito density has been already reported in Asia by K.T. Goh ${ }^{5}$, and S. K. Lam 6 . More studies are necessary to understand the characteristic eco-epidemiological factors of such regions as the Federal District.

\section{ACKNOWLEDGEMENTS}

Thanks are due to the technical staff of the FNS and ISDF (GCZ) who collected the mosquitoes and to the inhabitants for their kind collaboration.

\section{REFERENCES}

1. Araújo ESM, Luz DC, Santos FB, Miagostovich MP, Schatzmayr HG, Nogueira RMR. Dengue virus type 2 epidemic in the State of Rio de Janeiro, 1995. In: Resumos da $5^{\circ}$ Virológica 95, Ribeirão Preto, SP p. A37, 1995.

2. Dégallier N, Hervé J-P, Travassos da Rosa APA, Travassos da Rosa ES, Vasconcelos PFC, Monteiro HAO, Sá Filho G, Travassos da Rosa JFS. Entomological studies on Dengue fever vectors in Brazil: the epidemics of Boa Vista, Roraima, 1982, Niteroi, Rio de Janeiro, 1986, and Ceara State, 1986, 1994. In: Travassos da Rosa APA, Vasconcelos PFC, Travassos da Rosa JFS (eds) An overview of arbovirology in Brazil and neighbouring countries, Instituto Evandro Chagas, Belém, PA p. 261-271, 1998.

3. Dégallier N, Travassos da Rosa APA, Vasconcelos PF da C, Figueiredo LTM, Travassos da Rosa JFS, Rodrigues SG, Travassos da Rosa ES. La dengue et ses vecteurs au Brésil. Bulletin de la Société de Pathologie exotique 89:128-136, 1996.

4. Dusi RM, Vilarinhos PTR, Assis AL, Camara GL, Carvalho MS. Epidemiology of dengue in Federal District, Brazil, from 1994 to 1996. In: Abstracts of 1st International Seminar on Dengue, Rio de Janeiro, RJ p. 65, 1996.

5. Goh KT. Changing epidemiology of dengue in Singapore. The Lancet 346: 1098, 1995.
6. Lam SK. Prospects of Dengue surveillance and control in Malaysia. In: Uren MF, Blok J, Manderson LH (eds) Arbovirus Research in Australia. Proc. 5th Symp., August 28 - September 1, 1989, Brisbane, Australia p. 80-81, 1989.

7. Nogueira RMR, Schatzmayr HG, Miagostovich MP, Farias MFDB, Farias FC. Virological study of a dengue type 1 epidemic at Rio de Janeiro. Memorias do Instituto Oswaldo Cruz 83: 219-225, 1988.

8. Pires MFC, Teixeira JMS, Silva NC, Câmara GNL. Investigation of dengue in Distrito Federal, Brazil. In: Resumos da Virológica 91: II Simpósio Internacional sobre Arbovírus dos Trópicos e Febres hemorrágicas. Belém, PA p. 2, 1991.

9. Travassos da Rosa APA, Travassos da Rosa ES, Travassos da Rosa JFS, Dégallier N, Vasconcelos PFC, Rodrigues SG. Os arbovírus no Brasil: generalidades, métodos e técnicas de estudo, doc. técn. n`2, Instituto Evandro Chagas, Fundação Nacional de Saúde, Belém, 1994.

10. Vasconcelos PFC, Travassos da Rosa ES, Travassos da Rosa JFS, Freitas RB, Dégallier N, Rodrigues SG, Travassos da Rosa APA. Epidemia de febre clássica de dengue causada pelo sorotipo 2 em Araguaina, Tocantins, Brasil. Revista do Instituto de Medicina tropical de São Paulo 35: 141-148, 1993.

5isolates nr. 98043050 and 98043052 